\title{
1109 岩石の組成構造と力学的性質について
}

\begin{tabular}{|c|c|c|c|c|}
\hline 早稲田大学理工学部教授 - 工博 & ○田 & 中 & 正 & 男(正会員) \\
\hline 防衛庁技㭪研究本部第 4 研究所 & 種 & 田 & 啓 & 二(正会員) \\
\hline
\end{tabular}

\section{1. 緒}

\section{言}

坑内構造など地下構造設計や, 穿孔, 爆破など岩石掘 さくについて，対象岩石に応じた有効適切な対策を立て るに必要な基本的資料として，岩石の力学的性質を知る こそが必要であり，このため，一般に材料試験特性を利 用することが多いが，金属材料などの場合と異なり，少 量の試料による試験結果を全般に適用させるについて, 試料取扱いなどのごくわずかな差が敏感に影響し，值に バラッキがきわめて多くなり，一般的にその組成䊈造を 持つものの特性を代表させることを困難にしている。特 に“引張り”に関する特性值については, 組織敏感性に よるところ大であつて，值にバラッキが多くなり易いよ うである。たまたま，筆者らが二，三の岩石について材 料試験を行なつた際, める種の岩石については, 引張強 度について, 単純引張試験によるものと, 圧裂試験によ るものその間にかなりな差を生じ，かつ引張りに打ける ヤング率と圧縮に拈けるヤング率・ポアソン比との間に も同様大きな差異が認められたものがあつた。この原因 については,

（1） a）単純引張り試験に打ける偏荷重扣よびいわ ゆるチャック切れなどの問題，b）圧裂試験に打ける圧 縮面の拡がりの問題, その他の測定技術上の問題,

（2） a ）岩石の不均質性，識別困難なひび，節理な ぞの潜在的欠陥，b) 試料岩石の力学的履歷（試料採 取以前に受けた各種圧力の影響)，ｃ）岩石の組成構造 上の特性に関する問題，など岩石の構造に関する問題な ぞが考えられるが，他にもこのような差異を生じた実験 例1) が報告されているので，(2)c）の岩石の組成構造上 の特性と力学的性質との間に何らかの関係が存在するこ そも考えられ，これについて，どのような関連があるか その概略の傾向について検討するため，数種の岩石につ いて，前述の問題点を考慮しつつ，まず静荷重下に打け る力学的性質一材料試験的特性を調べたので，この結果 について述べる。な拉，現在までのところではまだ資料 が少なく，結論的なものを得るに至つていないが，一 応これまでに得られた実験結果について報告し，諸賢の 御教示を仰ぎたい。

\section{2. 実 験 方 法}

（1）試験項目：一般的な材料試験法に準じ，つぎの 各值を測定した。

（i）圧縮強度，(ii） 引張強度（単純引張・圧裂）, (iii）、圧縮扣よび引張りに扣ける縱（軸方向）歪・横歪， (iv) 曲げ強度，(v) その他，ショア硬度・靯性（ペ ージ落下衝撃) 試験,

また，岩石組成構造については，顕微鏡観察を行ない 粒子形状・結合状態・粒子の大きさ，执よび構成鉱物な

1）阿部・木下・中村 “岩石の引張強度および圧縮強度に関する 2,3 の実験的知見” 昭 39 年 4 月, 日本鉱業会誌 80 巻 909 号, （昭和 39 年 3 月) p. 207
ぞを調べた。

(2) 試験条件

(i ) 試料岩石：つぎのとおりである。

花崗岩 [茨城県稲田] - 石英閃緑岩 [群馬県水上町 (土 合付近)] - 花崗斑岩 [閃緑岩々同じ]・安山岩 $(A)[$ 群馬 県赤城] - 安山岩 $(B)$ [群馬県伊香保] - 石灰岩[栃木県葛 生]・セメントモルタル[セメント (C) : 普通ポルトラ ンド, 砂 $(\mathrm{S})$ : 川砂 (相模) ・花崗岩砕砂・標準砂, 各 粗粒率 $1 \sim 3, \mathrm{C} / \mathrm{W}=0.5 \sim 0.65, \mathrm{~S} / \mathrm{C}=2 / 1 \sim 4 / 1$, 養生 : 水中28日]

（ii）供試体寸法など：圧縮試験 $=25 \mathrm{~mm} \phi \times 50 \mathrm{~mm}$, 引張試験 : 単純 $=25 \mathrm{~mm} \phi \times 100 \mathrm{~mm}$ (第 1 図参照), 圧裂 $=25 \mathrm{~mm} \phi \times 40 \mathrm{~mm}$ ，（ただしセメントモルタル $=40 \mathrm{~mm} \phi$ $\times 80 \mathrm{~mm}, 40 \mathrm{~mm} \phi \times 30 \mathrm{~mm})$ の円筒形試料, 曲げ試験二 $40 \mathrm{~mm} \times 40 \mathrm{~mm} \times 120 \mathrm{~mm}$ 柱体（なお参考值として曲げ試 験後の残柱体 $40 \mathrm{~mm} \times 40 \mathrm{~mm} \times 40 \mathrm{~mm}$ 柱体について圧縮 試験を実施した）

（iii）実施要領：試験機は $20 \mathrm{t}$ アムスラー型万能試 験機を用い，荷重速度 $3 \sim 5 \mathrm{~kg} / \mathrm{cm}^{2} / \mathrm{sec}$ にて載荷した。 単純引張試験は,試料端に接着剤にてキャップを取付け, 第 1 図のごとく試験機にセットし, 偏荷重を防いだ。曲 げ試験は，標準モルタル試験用器具を用い，スパンッ 100 $\mathrm{mm}$ で中央集中荷重をかけ, $\sigma_{b}=M / Z$ より, 破壊応力 を求めた。荷重に対する各歪測定は試料岩石にワイヤス トレンゲージ（クロスゲージ C21）を貼り，DS6R 動歪計・電磁オッシロを用い，ロードセルを入れて載荷 し，荷重変化に応じた歪変化を自記記録させた。

\section{3. 実験結果および結果の検討}

$3 \cdot 1$ 各種強度試験結果：各種強度試験の結果は第 1 表に示すと拈りである。また，各岩石についての軸方向

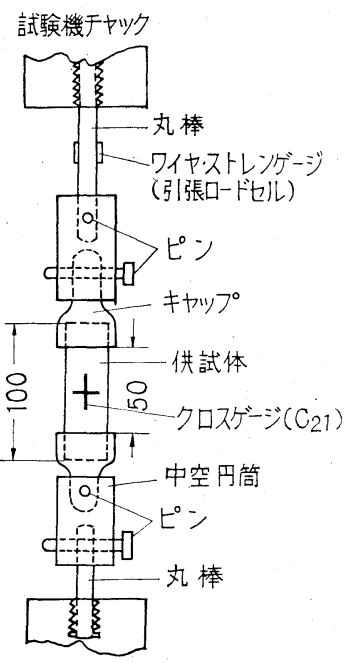




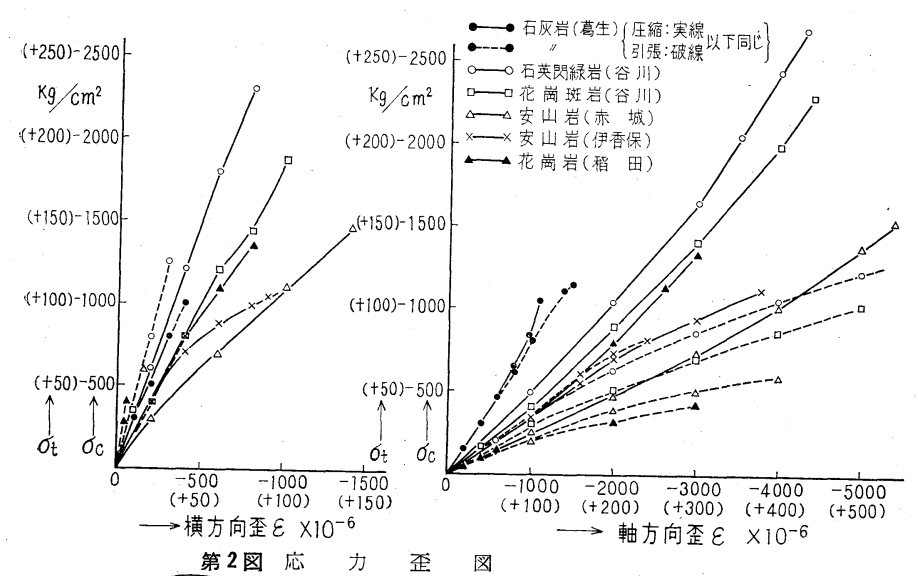

- 横方向歪一応力図は第 2 区に示す とおりである。図中圧縮・引張りで は向き扣よび単位が異なるが比較の 便宜のため一緒に記載した。

これより,まず最も顕著な傾向と して, 安山岩 $(\mathrm{B})$ を除き火成岩類で は引張りヤング率が圧縮ヤング率に 比し，かなり低くなつていること， 拉よび単純引張り強度々圧裂強度 との間に差が認められることがあ る。もつとも大きな差があるのが花 崗岩で, 差が少ないのが安山岩( B) と石灰岩扣よびモルタルである。こ のような差が組成樍造と何らかの関 係を有するか検討してみる。まず， 第 3 図に各岩石の顕微鏡観察の結果

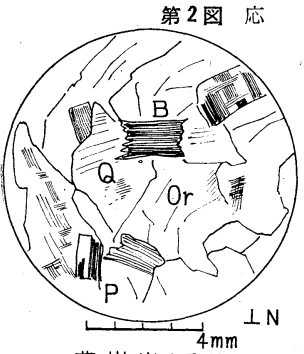

花崗岩(稻田)

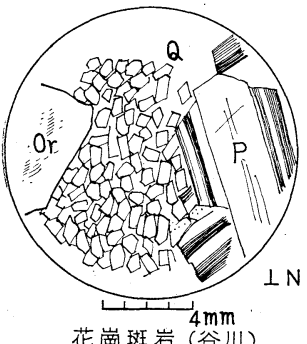

花崗斑岩 (谷川)

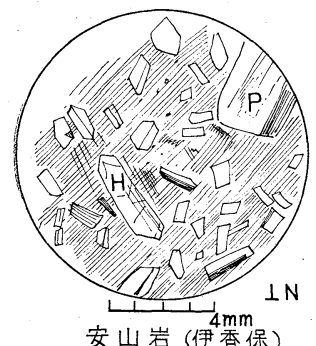

安山岩( 伊香保)

$\mathrm{Q}$ : 石蕉

$\mathrm{B}$ : 黑雲母 $\mathrm{P}$ : 斜長石 $\mathrm{E}$ : 頑火輝石

第3図各岩石の組成
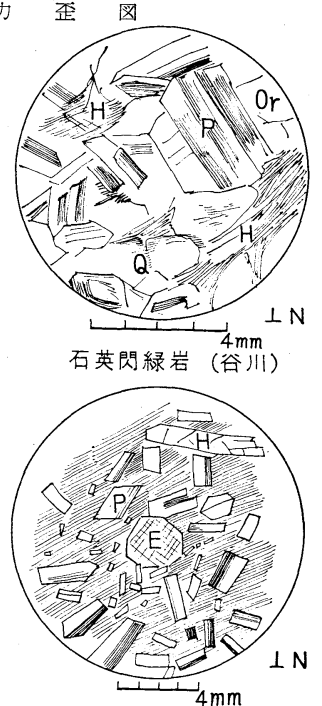

安山岩 (赤城)

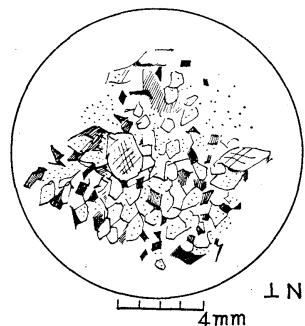

灰宸 (葛生)

第 1 表 岩石強度陚験結果

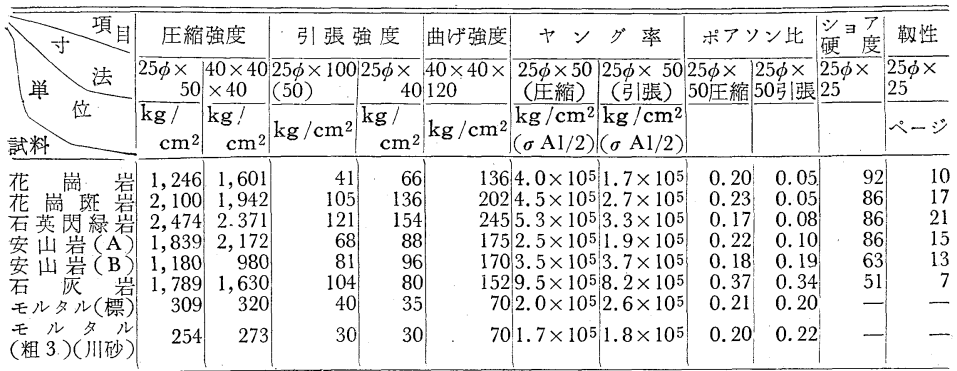

$194\langle 14\rangle$

を示す。これよりみると，ここで取上げたるののみにつ いては, 微粒結合(石灰岩, 安山岩 $(B)$ ) の るのは, 相対 的に引張りヤング率が大であり粗粒結合：大結晶が互い に接し, 組合つているもの（花崗岩など）は，相対的に 引張りヤング率が小でめる。引張り強度は圧縮強度に比 して, きわめて小さいので, 引張り歪は応力のごく小さ いところの動きである。したがつてこれを下村・高多ら のいう“第 1 相" ”内の挙動として説明することができ, 微粒結合のものは圧力の増加につれての変形（粒子の远 り）が比較的均一であるといえる。粗粒結合のものは小 さな圧力で急激に迄るが，その後は粒子組合せのせり合 いで歪は小さくなり，或る域まで安定するが，せり合いを 解かれる方向には过りを生じ易く，庄縮に打壮る横歪， 引張りにおける軸方向歪は大きくなるものと考えられ る。この事から，岩石の樍成は，相対的に bond による ものより, frictions による影響が大きく，この傾向に 対応する力のかかり方によつて抵抗の大小が決ると思わ れる。

単純引張強度と圧裂引張強度との差に対する説明資料 は現在までのところ，はつきりと得られていないが，以 上の構造的な差異が何らかの原因になつているよ５に思 われる。

\section{4. 結言}

本実験では，一般的な材料試験的特性を数種の岩石に ついて求め, 岩石組成構造との関連について検討しょう 々試みたが，資料数も不足でめつて不確定要素が多く， 結論的なるのは得られなかつたが, 今後, 更に実験を進 め, 荷重速度の変化によつてどのような挙動を示すかに ついても検討し，岩石破猿機棈解明などの手がかりとし たい。
2) 下村・高多：“岩石の力学的挙動 と破壞飞ついて (第 2 報)”日本 鉱業会誌, 昭36年10月, p871 